\title{
REVIEW
}

\section{Assessing the evidence of 'infertile' sea turtle eggs}

\author{
Andrea D. Phillott ${ }^{1, *}$, Matthew H. Godfrey ${ }^{2,3,4}$ \\ ${ }^{1}$ FLAME University, Pune, Maharashtra 412115, India \\ ${ }^{2}$ North Carolina Wildlife Resources Commission, Beaufort, NC 28516, USA \\ ${ }^{3}$ Duke Marine Laboratory, Nicholas School of Environment, Duke University, Beaufort, NC 28516, USA \\ ${ }^{4}$ Department of Clinical Sciences, College of Veterinary Medicine, North Carolina State University, Raleigh, NC 27695, USA
}

\begin{abstract}
There is increasing concern about feminization of sea turtle populations resulting from female-biased production of hatchlings due to climate change and selective loss of males from other anthropogenic drivers. Extreme female-biased breeding populations would reduce the likelihood of successful mating and potentially result in high rates of infertile eggs. Infertile eggs are those in which none of the events between sperm penetration of the ovum and syngamy have occurred. Distinguishing between fertile and infertile eggs is challenging, especially in field conditions, and researchers often have relied on physical evidence gathered from unhatched eggs at the end of the incubation period, which likely have experienced tissue decomposition. We argue that infertility in sea turtle eggs can be demonstrated only by the absence of holes caused by sperm penetration of the inner perivitelline membrane; sperm bound between the inner and outer perivitelline membranes; nuclei in the blastodisc; embryonic tissue or membranes in egg contents; and/or the characteristic white spot on the egg exterior. Unhatched eggs can be examined at the end of the incubation period, but we recommend that studies specifically investigating infertility examine at least 20 oviposited eggs each from clutches laid by at least 20 different turtles at the peak of the nesting season.
\end{abstract}

KEY WORDS: Sea turtle $\cdot$ Egg $\cdot$ Embryo $\cdot$ Fertile $\cdot$ Infertile $\cdot$ Fertilization $\cdot$ Feminization

\section{INTRODUCTION}

The number of live hatchlings produced from sea turtle eggs is commonly recorded by most sea turtle nesting beach monitoring projects and used to estimate hatching success of a clutch, defined as the number of hatchlings produced, divided by the number of yolked eggs deposited (Miller 1999). Hatching success is often used to assess various conservation actions, including nest relocation, predator control, and beach nourishment (e.g. Eckert \& Eckert 1990, Steinitz et al. 1998, Engeman et al. 2003, García et al. 2003, Abd Mutalib \& Fadzly 2015). In addition, examination of dead embryos found within unhatched eggs that remain in the nest cavity after the live

${ }^{*}$ Corresponding author: andrea.phillott@gmail.com hatchlings emerge can provide insight into when embryonic development stopped and thus provide temporal clues of the possible causes for embryonic mortality (e.g. tidal inundation, excessive rainfall, rough handling of eggs during relocation; Ragotzkie 1959, Abella et al. 2007, Hilterman \& Goverse 2007). Recently, Miller et al. (2017) published a generalized key to the stages of embryonic development of sea turtles, to facilitate the proper categorization of embryos that did not finish development. However, the early stages of embryonic development are challenging to recognize in the field, especially if eggs are investigated several weeks after embryonic mortality, which is usually the case for sea turtle nests that are inventoried after hatchling emergence.

(1) The authors 2020. Open Access under Creative Commons by Attribution Licence. Use, distribution and reproduction are unrestricted. Authors and original publication must be credited. 
In earlier publications of sea turtle biology and management, unhatched eggs without visible signs of embryonic development were categorized as infertile (e.g. Ragotzkie 1959, Balasingam 1967, Hughes \& Mentis 1967, Hughes et al. 1967, Schulz 1975, Fowler 1979, Kraemer \& Bell 1980, Stancyk et al. 1980, Chan et al. 1985, Hewavisenthi 1994, Peters et al. 1994). Fertility rates in leatherback turtles Dermochelys coriacea were assumed to be lower than in other sea turtle species (Balasingam 1967, Schulz 1975, Chan et al. 1985, Chan 1991, Chan \& Liew 1996), leading to the recommendation that egg fertility in this species be assessed before purchase and protection in hatcheries in Malaysia for incubation (Chan 1989). More recently, speculation about future extreme femalebiased production of hatchlings, due to climate change and temperature-dependent sex determination, has led to predictions of future lack of males in populations, and a concurrent increased rate of infertility in sea turtle eggs (Mrosovsky \& Godfrey 1995, Lovich 1996, Binckley et al. 1998, Glen \& Mrosovsky 2004, Laloë et al. 2014, Jensen et al. 2018). Extreme female-biased breeding populations could reduce the likelihood of successful mating (Bell et al. 2004, Abella et al. 2017) and potentially contribute to high rates of infertile eggs at specific rookeries (Booth \& Dunstan 2018) or in specific populations (Chan \& Liew 1996). Concern has also been expressed about the implications of reduced genetic variation in sea turtle populations due to environmental degradation and habitat loss (González-Garza et al. 2015), and the loss of males due to selective fishing practices (Abella et al. 2017), conservation actions (Mrosovsky \& Godfrey 1995), and use in traditional medicines (Martins et al. 2015) for future fertility rates of eggs.

However, the definition and best practice/s for assessment of 'infertile' sea turtle eggs have never been established. By definition, infertile eggs should include only those in which events between sperm penetration of the ovum and syngamy (fusion of the sperm and ovum pronuclei) have never occurred (see Birkhead et al. 2008). Assessment of egg infertility should therefore be based on evidence indicating the absence of fertilization or any embryonic development.

The few focused studies on egg fertility by experienced researchers using appropriate methods found that all eggs examined shortly after laying contained embryos (Table 1). Less experienced researchers may incorrectly assume that eggs are infertile if embryonic mortality occurred early in development and tissue had decomposed by the time failed eggs are examined at hatchling emergence (Blanck \& Sawyer 1981, Wyneken et al. 1988, Bell et al. 2004). Overall, the current methods used to assess the occurrence of infertile sea turtle eggs require a critical review based on an understanding of the process of fertilization and indicators of early embryonic development.

\section{FERTILIZATION AND EARLY EMBRYONIC DEVELOPMENT AND MORTALITY}

At ovulation, each follicle comprises material which becomes the egg yolk and a blastodisc (or germinal disc) upon which sits the germinal vesicle representing the oocyte nucleus (simply illustrated by Olszanska \& Stepinska 2008). Fertilization occurs in the anterior glandular region (magnum) of the oviduct (Solomon \& Baird 1979) with spermatazoa received during copulation and stored in sperm-storage tubules (Gist \& Jones 1989). Assuming post-fertilization changes in sea turtle follicles are similar to those of other amniotes, sperm penetration of the inner perivitelline membrane (PVM), which encompasses the follicle, over the blastodisc triggers formation of the outer PVM. The new membrane prevents polyspermy but binds sperm in contact with the follicle between the inner and outer PVMs (Birkhead et al. 1994). Embryonic development commences immediately after fertilization. Cleavage of the blastodisc begins within hours of fertilization, followed by blastulation and gastrulation. Embryonic development is arrested in mid-gastrulation (Stage 6; ap-

Table 1. Studies finding evidence of $>98 \%$ fertility rates in sea turtle eggs, based on detailed examination of egg contents and white spot development

\begin{tabular}{|c|c|c|}
\hline Source & Sea turtle & $\begin{array}{l}\text { Number of eggs } \\
\text { examined }\end{array}$ \\
\hline Limpus et al. (1984) & Leatherback & $\begin{array}{l}2 \text { eggs each from } 5 \\
\text { clutches at oviposition }\end{array}$ \\
\hline Wyneken et al. (1988) & Loggerhead & $\begin{array}{l}2 \text { eggs each from } 10 \\
\text { clutches at } 16-18 \mathrm{~h} \\
\text { post oviposition }\end{array}$ \\
\hline Miller et al. (2003) & Loggerhead & $\begin{array}{l}\text { 'Hundreds' of eggs at } \\
\text { oviposition }\end{array}$ \\
\hline Rafferty et al. (2013) & Green & 35 eggs from 2 clutches \\
\hline Rafferty \& Reina (2014) & Green & 97 eggs from 3 clutches \\
\hline Williamson et al. (2017a) & Green & 40 eggs from 6 clutches \\
\hline Williamson et al. (2017b) & Olive ridley & 303 eggs from 6 clutches \\
\hline
\end{tabular}


proximately Day 9 after ovulation) until oviposition (Miller 1985). This arrest is maintained by hypoxic conditions in the oviduct (Rafferty et al. 2013). Developmental arrest is broken within 12-16 h of oviposition (Williamson et al. 2017a) by exposure to atmospheric oxygen levels (Rafferty et al. 2013); embryonic development recommences and completes gastrulation followed by neurulation, organogenesis, and growth, with complementary formation of the extraembryonic membranes, adhesion of the vitelline and shell membranes, and vitelline circulation, until pipping at Stage 31 (Miller 1985). Stages of pre- and post-ovipositional embryonic development in sea turtles have been previously described and reviewed (Blanck \& Sawyer 1981, Crastz 1982, Miller 1985, Kaska \& Downie 1999, Miller et al. 2017); stages and $\%$ development time (\%DT, percentage of incubation period from oviposition to pipping for eggs incubated at $29^{\circ} \mathrm{C}$ ) described in this paper all refer to those based on Miller (1985) and Miller et al. (2017).

Distinguishing between infertility and early embryonic death is challenging (Miller 1997). Failed eggs may be incorrectly categorized as 'infertile' if mortality occurs before the embryo is visible upon inspection by eye. Intra-oviducal embryonic mortality can occur during gastrulation or developmental arrest, and potentially at higher rates if eggs are retained in the oviduct during a long inter-clutch interval (Rafferty et al. 2011, Booth \& Dunstan 2018; but also see Rings et al. 2015, Williamson et al. 2019). Embryos at this time are developed to Stages 1-6 (Miller 1985) and <2 $\mathrm{mm}$ in length (Miller 1985, Miller et al. 2017). Post-ovipositional early embryonic mortality, due to unsuitable temperature, moisture, or respiratory gas availability in the nest environment (Ragotzkie 1959, Foley et al. 2006, Howard et al. 2014, Bézy et al. 2015) or inappropriate movement while handling during sensitive periods (Limpus et al. 1979, Parmenter 1980, Chan et al. 1985), may also be difficult to discern before signs of embryonic development become visible to the unaided eye at approximately Stages 13-16 and an embryo length of $\sim 10 \mathrm{~mm}$ (Days 4-9 after oviposition) (Leslie et al. 1996, Ralph et al. 2005).

\section{STUDIES ASSESSING 'INFERTILITY'}

To date, many studies on the occurrence of infertility in sea turtle eggs have used the absence of a white spot on the egg exterior, and/or tissues representing embryonic development in the contents of failed eggs during their assessment.

\subsection{White spot on the egg exterior}

Soon after oviposition, the embryo becomes positioned at the top of the egg, adjacent to the shell membrane. The difference in specific gravities of yolk and albumen in the sea turtle egg and lack of chalazae (strands of albuminous material) result in the yolk rising through the albumen to a position at the top of the egg after oviposition (Blanck \& Sawyer 1981). As observed in crocodile eggs, the yolk is also likely to rotate within the albumen due to a density gradient created by formation of sub-embryonic fluid (see Webb et al. 1987). This positioning of the embryo during the first day of post-ovipositional development and further dehydration of the albumen as more sub-embryonic fluid is formed allows the vitelline membrane to adhere to the shell membrane and results in formation of a white spot on the shell exterior (Blanck \& Sawyer 1981, Webb et al. 1987). Membrane adherence likely changes the optical and structural properties of the eggshell as dehydration occurs, altering its appearance from translucent to opaque white and facilitating respiratory gas exchange (see Phillott \& Parmenter 2001, 2007). As the area of adherence increases progressively over time with embryonic development, the white spot on the exterior grows in size, until the entire eggshell is colored chalk-white (Miller 1985; our Table 2)

The absence of the characteristic white spot soon after oviposition has been used as an indication of infertility (e.g. Whitmore \& Dutton 1985, Chan 1989, Bell et al. 2004, Abella et al. 2007, 2017). However, the timing of inspection may influence its visibility, as there is evidence of variation in the duration between oviposition and white spot appearance (Table 2). Examining eggs too early may result in incorrect assessment. For example, Abella et al. (2017) assessed fertility rates in clutches of loggerhead turtle Caretta caretta in the days after oviposition and again after hatchling emergence; estimates of fertility were lower in $17 \%$ of clutches $(n=29)$ assessed using the white spot at $96 \mathrm{~h}$ after oviposition than estimates using embryo and tissue fragments in unhatched eggs after hatchling emergence.

\subsection{Embryonic tissue in egg contents}

Studies designed to carefully investigate fertility in sea turtle eggs have found embryos in $100 \%$ of eggs dissected at oviposition and at 16-18 h after oviposition (Table 1). However, early-stage embryos can be challenging to find under field conditions and/or by 
Table 2. Temporal variation in appearance of the characteristic 'white spot' on the sea turtle egg exterior and complete 'chalking' as the white spot encompasses the entire egg, among species and regional management units (RMU; as defined by Wallace et al. 2010). $(-)$ details not reported

\begin{tabular}{|c|c|c|c|c|c|c|}
\hline Source & $\begin{array}{l}\text { White } \\
\text { spot } \\
\text { formation }\end{array}$ & $\begin{array}{c}\text { Complete } \\
\text { chalking } \\
\text { of egg }\end{array}$ & Turtle & RMU & $\begin{array}{l}\text { Incubation } \\
\text { location }\end{array}$ & $\begin{array}{c}\text { Incubation } \\
\text { temperature } \\
\left({ }^{\circ} \mathrm{C}\right)\end{array}$ \\
\hline Caldwell (1959) & $2 \mathrm{~d}$ & $10-12 \mathrm{~d}$ & Loggerhead & - & - & - \\
\hline Blanck \& Sawyer (1981) & $<1 \mathrm{~d}$ & - & Loggerhead & NW ATL & Laboratory & $28 \pm 2 \mathrm{SD}$ \\
\hline Yntema \& Mrosovsky (1982) & $2 d$ & - & Loggerhead & NW ATL & $\begin{array}{l}\text { Long-distance } \\
\text { transport to laboratory }\end{array}$ & - \\
\hline Chan (1986) & $4-5 d$ & $20 \mathrm{~d}$ & Leatherback & - & Styrofoam boxes & $28-29$ \\
\hline Chan (1989) & $4-5 d$ & - & Leatherback & W PAC & Hatchery & - \\
\hline Marquez-M (1994) & $<1 \mathrm{~d}$ & $7 \mathrm{~d}$ & Kemp's ridley & NW ATL & In situ & - \\
\hline Kaska \& Downie (1999) & $<1 \mathrm{~d}$ & - & Green, Loggerhead & MED, MED & In situ & - \\
\hline Hewavisenthi \& Parmenter (2000) & $3 d$ & - & Flatback & SW PAC & Laboratory & 29.5 \\
\hline Abella et al. (2007) & $>24 \mathrm{~h}$ & - & Loggerhead & NE/NW ATL & In situ & - \\
\hline Mrosovsky et al. (2009) & $<27 \mathrm{~h}$ & & Hawksbill & W ATL & $\begin{array}{l}\text { Long-distance } \\
\text { transport to laboratory }\end{array}$ & - \\
\hline Rafferty et al. (2013) & $1-2 d$ & - & Green & SW PAC & $\begin{array}{l}\text { Long-distance } \\
\text { transport to laboratory }\end{array}$ & 28 \\
\hline Rafferty \& Reina (2014) & $1-2 d$ & - & Green & SW PAC & $\begin{array}{l}\text { Long-distance } \\
\text { transport to laboratory }\end{array}$ & $24,28,32$ \\
\hline Abella et al. (2017) & $>24 \mathrm{~h}$ & - & Loggerhead & NE/NW ATL & Laboratory & $26-30$ \\
\hline Williamson et al. (2017a) & $1-2 d$ & - & Green & SW PAC & Laboratory & 28 \\
\hline Williamson et al. (2017b) & $1-2 d$ & - & Olive ridley & E PAC & Laboratory & 28 \\
\hline Williamson et al. (2019) & $1 \mathrm{~d}$ & - & Olive ridley & E PAC & Laboratory & 28 \\
\hline
\end{tabular}

novice researchers (Wyneken et al. 1988, Kaska \& Downie 1999, Bell et al. 2004). For example, Blanck \& Sawyer (1981) examined 5 eggs each from 10 loggerhead turtle clutches, fixed within 2 h of oviposition, and were unable to find any embryos; they assumed that embryos were too small to discern at this stage. Even at 2-3 d post oviposition, the length of the embryonic disc measured only a few millimeters and was unpigmented (Crastz 1982, Miller 1985, Kaska \& Downie 1999, Miller et al. 2017). Extra-embryonic membranes, which may appear as tissue fragments in failed eggs, form only $\sim 36 \mathrm{~h}$ post oviposition (Blanck \& Sawyer 1981). Blood islands and the first blood cells form at Stage $11\left(5.7 \pm 0.5 \% \mathrm{DT}_{\text {; }} \sim 3-4 \mathrm{~d}\right.$ post oviposition) and vitelline circulation commences at Stage $13-14\left(7.6-8.6 \pm 0.5 \% \mathrm{DT}_{\mathrm{i}} \sim 4-7 \mathrm{~d}\right.$ post oviposition) (Yntema 1968, Ewert 1985, Miller 1985, Miller et al. 2017), which is why blood may not be visible to the unaided eye until after $4 \mathrm{~d}$ of development (Leslie et al. 1996, Ralph et al. 2005). In the absence of macroscopic signs of an embryo, blood or other tissues (and/or a white spot), failed fertilized eggs have been categorized incorrectly as infertile (e.g. Whitmore \& Dutton 1985, Bell et al. 2004, 2010), due to insufficiently close examination.

\section{BEST PRACTICES AND POTENTIAL TECHNIQUES FOR ASSESSING INFERTILITY IN SEA TURTLE EGGS}

There is a broad need to better understand factors, including the potential for infertility, that influence sea turtle hatchling production (Hamann et al. 2010, Rees et al. 2016). The best practices and potential techniques for assessing evidence of infertility in sea turtle populations and distinguishing between infertile eggs and those experiencing intra-oviducal or early embryonic mortality are described in Sections 4.1-4.3; the order of presentation is based on both rigor of outcomes and ease of application depending on available resources. We did not find any relevant studies that used methods for extraction and amplification of haploid DNA to distinguish between the germinal vesicle on an unfertilized follicle and the haploid cells comprising the blastodisc in a fertilized egg (see Arnold et al. 2003). If available, such a test would likely be more successful when applied to freshly oviposited eggs.

Bell et al. (2004) could not identify embryos or tissues in a small proportion of eggs that developed white spots but later failed to hatch, and Abella et al. (2017) estimated lower rates of fertility using pres- 
ence/absence of the white spot in the first few days of incubation than in the same clutch using embryo and tissue fragments in unhatched eggs at the end of the incubation period. Therefore, we recommend a combination of techniques be used and that tests finding no indications of fertilization and/or embryonic development in unhatched eggs at the end of the incubation period which have undergone decomposition be repeated using freshly oviposited eggs. This is especially important if the research objective is to quantify infertility rates.

\subsection{Examination of egg contents for embryonic development}

Parmenter (1980) challenged the assumption of infertility unless microscopic examination failed to find any evidence of embryonic development. The procedures below are suitable for fresh eggs at oviposition or unhatched eggs at the end of the incubation period. However, examination of failed eggs for indications of embryonic development would be most successful if conducted soon after embryonic death, as even dead, 3 wk old embryos have been known to disintegrate by the time of nest excavation at $9 \mathrm{wk}$ (Wyneken et al. 1988).

The turtle egg can be opened by hand or with fine scissors and examined for signs of an embryo, blood, or other tissue as evidence of fertilization. If none are visible macroscopically, the albumen should be discarded and the yolk placed in a watch glass or petri dish with the blastodisc or embryo (appearance described below) upwards for easiest examination. The blastodisc or embryo in a recently oviposited egg will be at a variable location on the yolk. Once the egg contents become re-organized by specific gravity after oviposition, the blastodisc or embryo will be located at the top of the yolk and immediately adjacent to the shell membrane; rotation should be minimized while removing eggs from the nest and the egg opened at a location other than its north pole. If decomposition has occurred between embryonic mortality and egg examination, and the yolk has become mixed with the albumen, the egg contents should be placed in a petri dish with a small volume of phosphate-buffered saline and carefully sorted.

In unfertilized eggs, the blastodisc will appear as a dense white spot alone and may seem granular due to the presence of abundant vacuoles. In fertilized eggs at the blastoderm stage, the blastodisc has undergone cleavage (see Stages 1-5 in Miller 1985 for descriptions), and the resulting blastoderm can be seen as a central, pale area pellucida surrounded by the dense, white ring of the area opaca. The one cell thick area pellucida is formed as cells in the center of the blastoderm are shed and die; the embryonic shield, the area which will undergo further differentiation during embryonic development, may be visible at its posterior location within the area pellucida. The area opaca represents the area of the blastoderm that has not shed its deeper cells. (For guiding images and potential variations in appearance as described in the freshwater turtle and avian literature, see Nayar 1958, Ewert 1985, Bakst et al. 1998, Onbaşilar et al. 2006, Birkhead et al. 2008.) In fertilized eggs where development has proceeded to a gastrula or later stage, embryo appearance will be as described by Miller et al. (2017). A dissecting microscope or hand lens (minimum magnification power $10 x$, with illumination via lamp or handheld light as appropriate; Miller et al. 2017) may be required to see the blastodisc, blastula, gastrula, or small embryo. Mounting tissue on a slide (Birkhead et al. 2008) and/or a biological stain (equal parts methylene blue and $70 \%$ ethanol; Bell et al. 2004) can also aid examination.

\subsection{Examination of egg exterior for the white spot}

Monitoring for appearance of the characteristic white spot in the first days of incubation may be used as a complementary assessment to examination of egg contents for embryonic tissue. Visual examination for a white spot can be conducted on eggs incubated in situ, in a relocated location elsewhere on the beach or a hatchery, or under appropriate laboratory conditions. It should not be used as the sole technique if the research objective is to specifically quantify infertility, due to the likelihood of underestimating fertility, as eggs that fail to develop a white spot will include those that were not fertilized plus those that were fertilized but experienced intra-oviducal death or early post-ovipositional death (Miller 1985). Bell et al. (2004), Ralph et al. (2005), and Rafferty et al. (2011), but not Eckert \& Eckert (1990), found that the majority of embryonic mortality occurred at Stage 6 (intra-oviducal arrested development to oviposition) or earlier, before the embryo had likely attached to the eggshell membrane and resulted in the formation of a white spot. Researchers should also be aware that the white spot can fade within $\sim 44 \mathrm{~h}$ of embryonic death (Phillott \& Parmenter 2007) and the chalk-white coloration may not appear on both viable (Sahoo et al. 2009) and non-viable (Phillott \& Parmenter 2007) unhatched eggs at the 
end of the incubation period. Thus, for eggs inspected within 1-5 d after oviposition, presence of the white spot definitively indicates that an egg was fertilized (Blanck \& Sawyer 1981, Miller 1985), but an egg without a white spot cannot be definitively categorized as infertile and requires further inspection.

\subsection{Candling to visualize the embryo and extra-embryonic membranes}

At oviposition, the sea turtle embryo (Stage 6; Miller et al. 2017) may be visible during candling, but extra-embryonic membranes (including the chorioallantois) are not present at this time (Miller 1985), so the suitability of this technique in oviposited eggs requires validation. Abella et al. (2017) observed signs of embryonic development by candling at $24 \mathrm{~h}$ post oviposition, although it is unclear if eggs in which structures were not found by candling showed other signs of embryonic development. If candling is used on recently oviposited eggs, negative findings should be followed by examination of the egg exterior for a white spot at the appropriate time or of egg contents for signs of embryonic development as described in Sections 4.1 and 4.2.

\subsection{Indications of sperm penetration of the ovum and syngamy}

Egg fertilization comprises a sequence of events, including sperm penetration of the inner perivitelline membrane and fusion of the haploid sperm and ovum pronuclei (syngamy) to form a diploid nucleus (see Birkhead et al. 2008). The techniques described look for indications of successful events in fertilization and, while also independently applicable, should be used in sea turtle populations for which examination of the egg contents aided by microscopy has consistently failed to locate embryonic or other tissue before conclusions about the frequency of infertile eggs are made.

\subsubsection{Holes in the PVM}

In birds, sperm penetration of the inner PVM over the blastodisc creates visible holes (Bramwell et al. 1995, Birkhead et al. 2008) which, even though the interval between fertilization and oviposition is longer, may be visible in sea turtle eggs. Holes were visible in unhatched tree sparrow eggs after $25 \mathrm{~d}$ of incubation and up to $15 \mathrm{~d}$ of cool storage (Birkhead et al. 2008), so the technique also shows promise for turtle eggs with no visible signs of development that are examined during or at the end of the incubation period. The technique required a piece of the blastodisc be removed from the yolk, and the inner PVM to be isolated and examined using light microscopy (see Bramwell et al. 1995, Birkhead et al. 2008).

\subsubsection{PVM-bound sperm}

Tests for evidence of sperm trapped in the PVMs have been described for birds (Birkhead et al. 1994, 2008), freshwater turtles (Croyle et al. 2016), and crocodiles (Augustine 2017) and may also have applications for sea turtles. Croyle et al. (2016) used a preparation of the PVMs followed by staining with the nucleic acid dye Hoechst 33342 and fluorescence microscopy to detect PVM-bound sperm in eggs from 12 freshwater turtle species; see Birkhead et al. (2008) for further explanation of the methods. The spermstaining test was successfully used on eggs which were maintained under different incubation and storage conditions. However, the dye will also stain fungal and bacterial DNA (Croyle et al. 2016), which can lead to a false positive for fertilization, so care must be taken when distinguishing between sperm heads and microbes in contaminated and infected eggs.

PVM-bound sperm in the radiated tortoise Astrochelys radiata, African spurred tortoise Centrochelys sulcata, and leopard tortoise Stigmochelys pardalis were also detected by mitochondrial DNA amplification and sequencing (technique and primers further described by Croyle et al. 2016). With appropriate primers, this technique should also be successful with sea turtle samples.

Further research on techniques to detect PVMbound sperm is needed in order to evaluate their utility for examining unhatched sea turtle eggs that have been recovered from nests at the end of the incubation period. As an additional note, the absence or low numbers of PVM-bound sperm in freshly oviposited eggs collected from a representative sample of females in a population is potentially the most reliable indicator of limited numbers of breeding males currently available.

\subsubsection{Detection of nuclei in the blastodisc}

The presence of numerous cell nuclei in the blastodisc indicates successful fertilization and cleavage. 
A piece of the blastodisc may be removed from the yolk and PVMs (see Gupta \& Bakst 1993, Birkhead et al. 2008) and then stained with Hoechst dye (see Birkhead et al. 2008; given as 'Hoechst 33324' in that study, but believed to be Hoechst 33342) and examined using fluorescence microscopy. Nuclei will be stained bright blue and can be quantified in fertilized eggs; the absence of nuclei indicates that the egg was not fertilized (Birkhead et al. 2008). Nuclei were detected in the blastodisc of fertilized but unhatched tree sparrow eggs after $25 \mathrm{~d}$ of incubation and up to $15 \mathrm{~d}$ of cool storage (Birkhead et al. 2008), so the technique also shows promise for failed turtle eggs examined during or at the end of the incubation period.

\subsection{Other techniques}

Recently described techniques for distinguishing between fertilized and unfertilized bird eggs at oviposition include measuring gas exchange rates using a customized microtesting examination platform (see Wang et al. 2017) and hyperspectral imaging technology (Zhu et al. 2015). These techniques have yet to be used in additional studies and taxa, so their potential application for turtle eggs is unknown; however, we believe that the other techniques described above will be more easily applied in sea turtle research in the future, due to increased availability of equipment and/or potential application in the field.

\section{RECOMMENDATIONS}

The window between initial fertilization and the end of successful egg incubation in sea turtles often spans $>50 \mathrm{~d}$, and the conditions in the nest cavity are highly conducive to tissue degradation of early stage embryos that have died. This greatly limits the ability of researchers to accurately determine whether unhatched sea turtle eggs are indeed fertilized. Thus, we believe that researchers must assume a greater burden of proof before designating unhatched eggs without signs of egg development as infertile. There is no evidence to date of depensation occurring in sea turtle populations (Bell et al. 2010, Wright et al. 2012, Abella-Perez et al. 2016), so such a burden of proof is especially important if rates of 'infertility' are used as justification for local conservation action, including removal of 'infertile' eggs from the nest (Abella et al. 2007) or manipulation of the nest environment via shading, watering, or other means to increase pro- duction of male hatchlings (Hill et al. 2015, Jourdan \& Fuentes 2015).

The gold standard for assessing rates of fertility is to evaluate freshly oviposited eggs for the presence of embryonic development (e.g. Wyneken et al. 1988). Given the lack of baseline information on fertility rates of sea turtle eggs, we recommend dedicated studies be undertaken to document rates of fertility of various rookeries and regional management units. Given that the outcome for each egg is binary (fertilized or unfertilized), having sufficient power to detect significant differences in average fertility rates across clutches with $>100$ eggs requires that at least 20 eggs per clutch are examined to generate a fertility ratio (Spotila et al. 1983, Mrosovsky et al. 2009). To derive a simple fertility estimate of a nesting population, we recommend examining 20 eggs from 20 clutches laid by different females during an $8 \mathrm{~d}$ period (to avoid collecting eggs laid by the same female) at the peak of the nesting season. More sampling will be needed to examine potential changes in fertility rates across the season, both in individual females and in the population as a whole. Rigorous sampling should also be applied to nesting populations demonstrating hatching success in undisturbed nests that is below the normal range (e.g. $<60 \%$ for loggerheads, Dodd 1988; <70\% for green turtles Chelonia mydas, Hirth 1997) and cannot be attributed to factors other than infertility. However, given the ethical and permitting constraints of sacrificing viable eggs for this type of study, researchers must determine what the most appropriate sampling regime is for their study population.

In addition, when describing and categorizing eggs at the end of the incubation period, we recommend the terms 'fertile' and 'infertile' and the related forms for each be used with the strictest of accuracy according to their definition to ensure naïve researchers and conservationists do not try to address issues that have not been conclusively demonstrated, let alone quantified. Parmenter (1980) recommended that the term 'undeveloped' be applied to eggs that show no macroscopic signs of development at the end of the incubation period and to avoid using the term 'infertile' (as inappropriately applied by Hughes \& Mentis 1967, Hughes et al. 1967, Simon 1975, Simon et al. 1975, Peters et al. 1994, Hitchins et al. 2004, Bell et al. 2010, Önder \& Candan 2016, Abella et al. 2017). Furthermore, we recommend that hatching and/or emergence success not be used as a proxy for fertility. These measures are more appropriately used as proxies for reproductive success, with the understanding that many environmental factors affect the 
hatching rate of incubating sea turtle eggs (Miller et al. 2003). While fertility rates and hatching/emergence success values may be related, they should be assessed separately.

Currently, the lack of information on fertility in sea turtle eggs hampers deeper understanding of the potential impacts of climate change on sea turtle populations. We encourage validating the techniques suggested above that have yet to be trialed with sea turtle eggs, and conducting appropriately designed studies to quantify rates of fertility and infertility in different sea turtle populations.

\section{LITERATURE CITED}

Abd Mutalib AHA, Fadzly N (2015) Assessing hatchery management as a conservation tool for sea turtles: a case study in Setiu, Terengganu. Ocean Coast Manag 113: 47-53

Abella E, Marco A, López-Jurado LF (2007) Success of delayed translocation of loggerhead turtle eggs. J Wildl Manag 71:2290-2296

Abella E, García-Cerdá RM, Marco A (2017) Estimating the fertilization rate of sea turtle nests: comparison of two techniques. Basic Appl Herpetol 31:33-44

Abella Perez E, Marco A, Martins S, Hawkes LA (2016) Is this what a climate change resilient population of marine turtles looks like? Biol Conserv 193:124-132

Arnold KE, Orr KJ, Griffiths R (2003) Primary sex ratios in birds: problems with molecular sex identification of undeveloped eggs. Mol Ecol 12:3451-3458

Augustine L (2017) Crocodile perivitelline membranebound sperm detection. Zoo Biol 36:213-219

Bakst MR, Gupta SK, Potts W, Akuffo V (1998) Gross appearance of the turkey blastoderm at oviposition. Poult Sci 77:1228-1233

Balasingam E (1967) The ecology and conservation of the leathery turtle Dermochelys coriacea (Linn.) in Malaya. Micronesica 3:37-43

Bell BA, Spotila JR, Paladino FV, Reina RD (2004) Low reproductive success of leatherback turtles, Dermochelys coriacea, is due to high embryonic mortality. Biol Conserv 115:131-138

Bell CD, Blumenthal JM, Broderick AC, Godley BJ (2010) Investigating potential for depensation in marine turtles: How low can you go? Conserv Biol 24:226-235

Bézy VS, Valverde RA, Plante CJ (2015) Olive ridley sea turtle hatching success as a function of the microbial abundance in nest sand at Ostional, Costa Rica. PLOS ONE 10:e0118579

* Binckley CA, Spotila JR, Wilson KS, Paladino FV (1998) Sex determination and sex ratios of Pacific leatherback turtles, Dermochelys coriacea. Copeia 1998:291-300

Birkhead TR, Sheldon BC, Fletcher F (1994) A comparative study of sperm-egg interactions in birds. J Reprod Fertil 101:353-361

Birkhead TR, Hall J, Schut E, Hemmings N (2008) Unhatched eggs: methods for discriminating between infertility and early embryo mortality. Ibis 150:508-517

Blanck CE, Sawyer RH (1981) Hatchery practices in relation to early embryology of the loggerhead sea turtle, Caretta caretta (Linné). J Exp Mar Biol Ecol 49:163-177

* Booth DT, Dunstan A (2018) A preliminary investigation into the early embryonic death syndrome (EEDS) at the world's largest green turtle rookery. PLOS ONE 13:e0195462

*Bamwell RK, Marks HL, Howarth B (1995) Quantitative determination of spermatozoa penetration of the perivitelline layer of the hen's ovum as assessed on oviposited eggs. Poult Sci 74:1875-1883

Caldwell DK (1959) The loggerhead turtles of Cape Romain, South Carolina. Bull Fla State Mus 4:317-348

Chan EH (1986) Development of the white spot on leatherback eggs. Mar Turtle Newsl 39:8

Chan EH (1989) White spot development, incubation and hatching success of leatherback turtle (Dermochelys coriacea) eggs from Rantau Abang, Malaysia. Copeia 1989:42-47

Chan EH (1991) Sea turtles. In: Kiew R (ed) The state of nature conservation in Malaysia. Malayan Nature Society, Kuala Lumpur, p 120-135

Chan EH, Liew HC (1996) Decline of the leatherback turtle population in Terengannu, Malaysia, 1956-1995. Chelonian Conserv Biol 2:196-203

Chan EH, Salleh HU, Liew HC (1985) Effects of handling on hatchability of eggs of the leatherback turtle, Dermochelys coriacea (L.). Pertanika 8:265-271

Crastz F (1982) Embryological stages of the marine turtle Lepidochelys olivacea (Eschscholtz). Rev Biol Trop 30: 113-120

Croyle K, Gibbons P, Light C, Goode E, Durrant B, Jensen T (2016) Chelonian perivitelline membrane-bound sperm detection: a new breeding management tool. Zoo Biol 35: 95-103

Dodd CK Jr (1988) Synopsis of the biological data on the loggerhead sea turtle Caretta caretta (Linnaeus 1758). US Dept Interior Fish and Wildl Serv Biol Rep 88. US Fish and Wildlife Service, Washington, DC

* Eckert KL, Eckert SA (1990) Embryonic mortality and hatch success of in situ and translocated leatherback sea turtle eggs, Dermochelys coriacea. Biol Conserv 53:37-46

*Engeman RM, Martin RE, Constantin B, Noel R, Woolard J (2003) Monitoring predators to optimize their management for marine turtle nest protection. Biol Conserv 113: 171-178

Ewert MA (1985) Embryology of turtles. In: Gans C, Billett F, Maderson PFA (eds) Biology of the Reptilia, Vol 14A. Development. Wiley-Interscience, New York, NY, p 75-267

Foley AM, Peck SA, Harman GR (2006) Effects of sand characteristics and inundation on the hatching success of loggerhead sea turtle (Caretta caretta) clutches on lowrelief mangrove islands in southwest Florida. Chelonian Conserv Biol 5:32-41

* Fowler LE (1979) Hatching success and nest predation in the green sea turtle, Chelonia mydas, at Tortuguero, Costa Rica. Ecology 60:946-955

* García A, Ceballo G, Adaya R (2003) Intensive beach management as an improved sea turtle conservation strategy in Mexico. Biol Conserv 111:253-261

Gist DH, Jones JM (1989) Sperm storage within the oviduct of turtles. J Morphol 199:379-384

Glen F, Mrosovsky N (2004) Antigua revisited: the impact of climate change on sand and nest temperatures at a hawksbill turtle (Eretmochelys imbricata) nesting beach. Glob Change Biol 10:2036-2045

González-Garza BI, Stow A, Sánchez-Teyer LF, Zapata- 
Pérez O (2015) Genetic variation, multiple paternity, and measures of reproductive success in the critically endangered hawksbill (Eretmochelys imbricata). Ecol Evol 5: 5758-5769

Gupta SK, Bakst MR (1993) Turkey embryo staging from cleavage through hypoblast formation. J Morphol 217: 313-325

Hamann M, Godfrey MH, Seminoff JA, Arthur K and others (2010) Global research priorities for sea turtles: informing management and conservation in the 21st century. Endang Species Res 11:245-269

Hewavisenthi S (1994) The embryo and hatchling mortality of the green turtle (Chelonia mydas) and olive ridley (Lepidochelys olivacea) in relation to clutch size. Herpetol J 4:73-76

Hewavisenthi S, Parmenter CJ (2000) Hydric environment and sex determination in the flatback turtle (Natator depressus Garman) (Chelonia: Cheloniidae). Aust J Zool 48: 653-659

Hill JE, Paladino FV, Spotila JR, Tomillo PS (2015) Shading and watering as a tool to mitigate the impacts of climate change in sea turtle nests. PLOS ONE 10:e0129528

Hilterman ML, Goverse E (2007) Nesting and nest success of the leatherback turtle (Dermochelys coriacea) in Suriname, 1999-2005. Chelonian Conserv Biol 6:87-100

Hirth HF (1997) Synopsis of the biological data on the green turtle Chelonia mydas (Linnaeus 1758). US Dept Interior Fish and Wildl Serv Biol Rep 97. US Fish and Wildlife Service, Washington, DC

Hitchins PM, Bourquin O, Hitchins S (2004) Nesting success of hawksbill turtles on Cousine Island, Seychelles. J Zool (Lond) 264:383-389

Howard R, Bell I, Pike DA (2014) Thermal tolerances of sea turtle embryos: current understanding and future directions. Endang Species Res 26:75-86

Hughes GR, Mentis MT (1967) Further studies on marine turtles in Tongaland, II. Lammergeyer 7:55-72

Hughes GR, Bass AJ, Mentis MT (1967) Further studies on marine turtles in Tongaland, I. Lammergeyer 7:5-54

Jensen MP, Allen CD, Eguchi T, Bell IP and others (2018) Environmental warming and feminization of one of the largest sea turtle populations in the world. Curr Biol 28: 154-159

Jourdan J, Fuentes MMPB (2015) Effectiveness of strategies at reducing sand temperature to mitigate potential impacts from changes in environmental temperature on sea turtle reproductive output. Mitig Adapt Strategies Glob Change 20:121-133

Kaska Y, Downie R (1999) Embryological development of sea turtles (Chelonia mydas, Caretta caretta) in the Mediterranean. Zool Middle East 19:55-69

Kraemer JE, Bell R (1980) Rain-induced mortality of eggs and hatchlings of loggerhead sea turtles (Caretta caretta) on the Georgia Coast. Herpetologica 36:72-77

Laloë JO, Cozens J, Renom B, Taxonera A, Hays GC (2014) Effects of rising temperature on the viability of an important sea turtle rookery. Nat Clim Chang 4:513-518

Leslie AJ, Penick DN, Spotila JR, Paladino FV (1996) Leatherback turtle, Dermochelys coriacea, nesting and nest success at Tortuguero, Costa Rica, in 1990-1991. Chelonian Conserv Biol 2:159-169

Limpus CJ, Baker V, Miller JD (1979) Movement-induced mortality of loggerhead eggs. Herpetologica 35:335-338

Limpus CJ, McLachlan NC, Miller JD (1984) Further observations on breeding of Dermochelys coriacea in Aus- tralia. Aust Wildl Res 11:567-571

Lovich JE (1996) Possible demographic and ecologic consequences of sex ratio manipulation in turtles. Chelonian Conserv Biol 2:114-117

Marquez-M R (1994) Synopsis of the biological data on the Kemp's ridley turtle, Lepidochelys kempi (Garman, 1880). NOAA Tech Memo NMFS-SEFSC-34

Martins S, Rocha F, Rodrigues E, Lopes SA, Abella E, Loureiro NS, Marco A (2015) The use of sea turtles in traditional medicine in the Cape Verde Archipelago, West Africa. Afr Sea Turtle Newsl 4:12-15

Miller JD (1985) Embryology of marine turtles. In: Gans C, Billett F, Maderson PFA (eds) Biology of the Reptilia, Vol 14A. Development. Wiley-Interscience, New York, NY, p 269-328

Miller JD (1997) Reproduction in sea turtles. In: Lutz PL, Musick JA (eds) The biology of sea turtles, Vol I. CRC Press, Boca Raton, FL, p 51-79

Miller JD (1999) Determining clutch size and hatching success. In: Eckert KL, Bjorndal KA, Abreu-Grobois FA, Donnelly M (eds) Research and management techniques for the conservation of sea turtles. Publication No. 4. IUCN/SSC Marine Turtle Specialist Group, p 124-129. www.iucn-mtsg.org/techniques-manual-english

Miller JD, Limpus CJ, Godfrey MH (2003) Nest site selection, oviposition, eggs, development, hatching, and emergence of loggerhead turtles. In: Bolten AB, Witherington BE (eds) Loggerhead sea turtles. Smithsonian Institution Press, Washington, DC, p 125-143

Miller JD, Mortimer JA, Limpus CJ (2017) A field key to the developmental stages of marine turtles (Cheloniidae) with notes on the development of Dermochelys. Chelonian Conserv Biol 16:111-122

Mrosovsky N, Godfrey MH (1995) Manipulating sex ratios: turtle speed ahead! Chelonian Conserv Biol 1:238-240

Mrosovsky N, Kamel SJ, Diez CE, van Dam RP (2009) Methods of estimating natural sex ratios of sea turtles from incubation temperatures and laboratory data. Endang Species Res 8:147-155

Nayar MC (1958) On gastrulation in Chelonia (Geoemyda trijuga coronata and Lissemys punctata granosa Schoepff). Proc Indiana Acad Sci 49b:402-407

Olszanska B, Stepinska U (2008) Molecular aspects of avian oogenesis and fertilization. Int J Dev Biol 52:187-194

Onbaşilar EE, Gúrcan IS, Kaplan G, Aksoy FT (2006) Gross appearance of the chicken unfertilized germinal disc. Ankara Univ Vet Fak Derg 53:215-217

光 Önder BF, Candan O (2016) The feminizing effect of metabolic heating in green turtle (Chelonia mydas) clutches in the eastern Mediterranean. Zool Middle East 62: 239-246

Parmenter CJ (1980) Incubation of the eggs of the green sea turtle, Chelonia mydas, in Torres Strait, Australia: the effect of movement on hatchability. Aust Wildl Res 7: 487-491

Peters A, Verhoeven KJF, Strijbosch H (1994) Hatching and emergence in the Turkish Mediterranean loggerhead turtle, Caretta caretta: natural causes for egg and hatchling failure. Herpetologica 50:369-373

*Phillott AD, Parmenter CJ (2001) Influence of diminished respiratory surface area on survival of sea turtle embryos. J Exp Zool 289:317-321

* Phillott AD, Parmenter CJ (2007) Deterioration of green sea turtle (Chelonia mydas) eggs after known embryo mortality. Chelonian Conserv Biol 6:262-266 
Rafferty AR, Reina RD (2014) The influence of temperature on embryonic developmental arrest in marine and freshwater turtles. J Exp Mar Biol Ecol 450:91-97

Rafferty AR, Santidrian Tomillo P, Spotila JR, Paladino FV, Reina RD (2011) Embryonic death is linked to maternal identity in the leatherback turtle (Dermochelys coriacea). PLOS ONE 6:e21038

Rafferty AR, Evans RG, Scheelings TF, Reina RD (2013) Limited oxygen availability in utero constrains the evolution of live-birth in reptiles. Am Nat 181:245-253

Ragotzkie RA (1959) Mortality of loggerhead turtle eggs from excessive rainfall. Ecology 40:303-305

Ralph CR, Reina RD, Wallace BP, Sotherland PR, Spotila JR, Paladino FV (2005) Effect of egg location and respiratory gas concentrations on developmental success in nests of the leatherback turtle, Dermochelys coriacea. Aust J Zool 53:289-294

Rees AF, Alfaro-Shigueto J, Barata PCR, Bjorndal KA and others (2016) Are we working towards global research priorities for management and conservation of sea turtles? Endang Species Res 31:337-382

Rings CC, Rafferty AR, Guinea ML, Reina RD (2015) The impact of extended preovipositional arrest on embryonic development and hatchling fitness in the flatback sea turtle. Physiol Biochem Zool 88:116-127

Sahoo G, Mohapatra BK, Dutta SK (2009) Structural changes in olive ridley turtle eggshells during embryonic development. Herpetol J 19:143-149

Schulz JP (1975) Sea turtles nesting in Surinam. Brill, Leiden

Simon MH (1975) The green sea turtle (Chelonia mydas): collection, incubation and hatching of eggs from natural rookeries. J Zool 176:38-48

Simon MH, Ulrich GF, Parkes AS (1975) The green sea turtle (Chelonia mydas): mating, nesting and hatching on a farm. J Zool 177:411-423

Solomon SE, Baird T (1979) Aspects of the biology of Chelonia mydas L. Oceanogr Mar Biol Annu Rev 17: 347-361

Spotila JR, Standora EJ, Morreale SJ, Ruiz GJ, Puccia C (1983) Methodology for the study of temperature related phenomena affecting sea turtle eggs. US Fish and Wildl Serv Endang Species Rep 11. US Fish and Wildlife Service, Washington, DC

Stancyk SE, Talbert OR, Dean JM (1980) Nesting activity of the loggerhead turtle Caretta caretta in South Carolina,

Editorial responsibility: Mark Hamann,

Townsville, Queensland, Australia
II. Protection of nests from racoon predation by translocation. Biol Conserv 18:289-298

Steinitz MJ, Salmon M, Wyneken J (1998) Beach renourishment and loggerhead turtle reproduction: a seven year study at Jupiter Island, Florida. J Coast Res 14:1000-1013

Wallace BP, DiMatteo AD, Hurley BJ, Finkbeiner EM and others (2010) Regional management units for marine turtles: a novel framework for prioritizing conservation and research across multiple scales. PLOS ONE 5:e15465

Wang Q, Fu D, Ma M, Zhang T (2017) Differentiating between fertilized and unfertilized eggs prior to incubation based on oxygen flux measurement. Int J Agric Biol Eng 10:243-251

Webb GJW, Manolis SC, Whitehead PJ, Dempsey K (1987) The possible relationship between embryo orientation opaque banding and the dehydration of albumen in crocodile eggs. Copeia 1987:252-257

Whitmore CP, Dutton PH (1985) Infertility, embryonic mortality and nest-site selection in leatherback and green sea turtles in Suriname. Biol Conserv 34:251-272

Williamson SA, Evans RG, Reina RD (2017a) When is embryonic arrest broken in turtle eggs? Physiol Biochem Zool 90:523-532

Williamson SA, Evans RG, Robinson NJ, Reina RD (2017b) Hypoxia as a novel method for preventing movementinduced mortality during translocation of turtle eggs. Biol Conserv 216:86-92

*Williamson SA, Evans RG, Robinson NJ, Reina RD (2019) Synchronised nesting aggregations are associated with enhanced capacity for extended embryonic arrest in olive ridley sea turtles. Sci Rep 9:9783

*Wright LI, Stokes KL, Fuller WJ, Godley BJ, and others (2012) Turtle mating patterns buffer against disruptive effects of climate change. Proc R Soc B 279:2122-2127

* Wyneken J, Burke TJ, Salmon M, Pedersen DK (1988) Egg failure in natural and relocated sea turtle nests. J Herpetol 22:88-96

*Yntema CL (1968) A series of stages in the embryonic development of Chelydra serpentina. J Morphol 125:219-251

* Yntema CL, Mrosovsky N (1982) Critical periods and pivotal temperatures for sexual differentiation in loggerhead sea turtles. Can J Zool 60:1012-1016

Zhu Z, Liu T, Xie D, Wang Q, Ma M (2015) Nondestructive detection of infertile hatching eggs based on spectral and imaging information. Int J Agric Biol Eng 8:69-76

Submitted: February 10, 2020; Accepted: February 18, 2020 Proofs received from author(s): March 23, 2020 